\title{
Exploration and Practice on Talent Training Modes for Mechanical Engineering in Application-Undergraduate Colleges
}

\author{
Ziyang Cao \\ College of Mechanical Engineering \\ Suzhou University of Science and Technology \\ Suzhou, China \\ e-mail:dukeczy@nuaa.edu.cn
}

\author{
Guangxun Wang \\ College of Mechanical Engineering \\ Suzhou University of Science and Technology \\ Suzhou, China \\ e-mail: guangxun_77@163.com
}

\begin{abstract}
With the rapid development of mechanical manufacturing industry, mechanical application type talents demand is increasing, as a local undergraduate colleges of professional mechanical, need to adjust its talents cultivation mode and scheme, so as to meet the needs of the market, serving the development of local economy. This article presents an analysis of cultivation characteristics using the concept of application-oriented talents for students majoring in the field of mechanical engineering. The mechanical engineering department formulated the corresponding aim and training program. Appropriate response measures have been taken according to problems within current application-oriented talents. This innovative method has been demonstrated over recent years and has achieved satisfactory results. Through undergraduate education exploration, the good response to the employment proves correctness and feasibility of this scheme, the use of these methods would allow successfully overcoming the bottleneck in the practice of application-oriented talent cultivation, and the mode is most beneficial for the cultivation of high-quality application-oriented talents.
\end{abstract}

Keywords-mechanical engineering; practical talent; training model; practical ability; creative ability

\section{INTRODUCTION}

The aim of mechanical engineering education is to teach basic theory and methods relevant to mechanically based manufacturing and technology. The education should cultivate the talent required by corporations, thus, reflecting market demand. With the rapid development of mechanical disciplines and fierce market competition, besides the solid foundation of theoretical knowledge, professional engineers also should have good practical ability [1-3]. Moreover, they are expected to understand engineering applications, be innovative, be able to analyze and solve problems, and acquire knowledge through selfstudy.

Countries such as Germany and the United States of America are powerful in mechanization, and their training of mechanical engineers is so fully developed that they provide a large supply of talent for the country's manufacturing industry [4-5]. It is a key issue for most developing countries: that they build a training mode of practical talent in mechanical engineering majors based on their own national conditions. The manufacturing industry, as a pillar industry of China's national economy, supports the economic and social development of the country and forms the basis of the nation's economic transformation [6-8]. Manufacturing is also the leading industry of Jiangsu Province. Thus, it is imperative to meet the growing demands of the workforce along with the need for highquality interdisciplinary application-oriented talents.

Currently, there are three popular international practical training models [9-10]. The first is the dual system mode as operated in Germany. The main task of cultivating talent is shared between businesses and schools. The school organizes the professional education and job training of the students in accordance with the requirements of business. Hence, the students are more proficient in the technical abilities required in jobs, and so quickly work well after graduation. The second mode is the competency-based education and it is used in Canada and the United States. The core of the training mode is to determine the competence objectives from the needs of professional positions. The mode uses a curriculum development committee composed of experts from business, who formulate a hierarchical table of competencies, which serves as the goals in setting curricula and organizing teaching content. Students are examined against these competencies. The third mode, technical and further education, is Australia's leading education and training provider. The mode combines government and industry with schools, and the schools are operated flexibly on the idea of student-centering.

In view of this practical and ever growing market demand for talent cultivation, Suzhou University of Technology plans to take advantage of the current development trend to reform its cultivation mode of application-oriented talents majoring in the field of mechanical engineering.

\section{Problems WITHIN CURRENT APPLICATION-ORIENTED TALENTS}

Application-oriented talents refer to individuals who can apply specialized knowledge and skills to professional practice. As specified by the cultivation objective of undergraduate-level talents, students receive basic engineering training during their academic years. To perform these activities, the application-oriented talents majoring in mechanical engineering need to be of high 
caliber with a range of skills and qualities that meet the demands of their responsibilities.

\section{A. The Mode is Less Diversified and Adaptive}

Current teaching mode is academic-oriented, which highlights the teaching of professional knowledge and overlooks the development of ability and comprehensive caliber as well as the configuration of such subjects as social development and economic environment including humanities and ecological view. For so many years, this has significantly hindered the development of Chinese engineering education, and as a result the students produced have narrow range of knowledge, poor innovation and learning abilities. Moreover, the colleges and universities ignore the training of students in team spirit, communication skill, systematic control ability, sense of responsibility, professional ethics, etc., so that the graduates are often confronted with a great many difficulties when they go into the real world.

\section{B. The Mode does not Involve Enough Practical Training}

Teaching of knowledge is paid much more attention to than training of practical ability. The rapid expansion of student population further weakens the necessary practice involvement in engineering education. In addition, there are a very limited number of teachers who have rich practical engineering experience. The engineering technological personnel produced by higher engineering education cannot apply theories to practice. After they go into the real world, they cannot directly take up jobs, but have to spend much time, energy and resources on learning practical operation.

\section{Conflict between Supply and Demand}

The academic-oriented personnel specialized in engineering have been produced through higher engineering education, which can basically meet the need of enterprises for senior professionals. However, the development of application-oriented personnel is neglected, so the urgent need of senior application-oriented personnel for economic and social development cannot be met well.

\section{Lack of Engineering Thinking Training}

In the background of modern engineering education, the separation model between school education and enterprise training is not conductive of future engineers. The new training mechanism should take the educational thought of "engineering view" as the guide, and emphasizes on the combination of engineering practice training model between schools and enterprises. The new mode focuses on the establishment of depth cooperation mechanism between schools and industry enterprises, through jointing training to increase students' learning and practice opportunities in enterprises and make them master theoretical knowledge in a real engineering practice solidly.

\section{RESPONSE MEASURES}

\section{A. Implementation of Engineering Awareness}

The essence of the new engineering education philosophy is such a large-scale engineering concept that calls for balance between human beings and social development and balance between prosperity of natural ecology and engineering technology progress, and training people to achieve individualized development based on scientific construction and social demands as well as in favor of industrial interests. Engineering education in China's higher education institutions should experience further transformation, and science and technology education and humanities education should be integrated. The Fig .1 indicates the basic idea that help build up talents training mode of mechanical major. Engineering technology should be regarded as the core, with humanities courses serving as supplement, to break the boundary of specialty and broaden knowledge range. Students should be trained for comprehensive, integrated and systematic thinking, and rich engineering knowledge background and enhanced comprehensive engineering application ability.

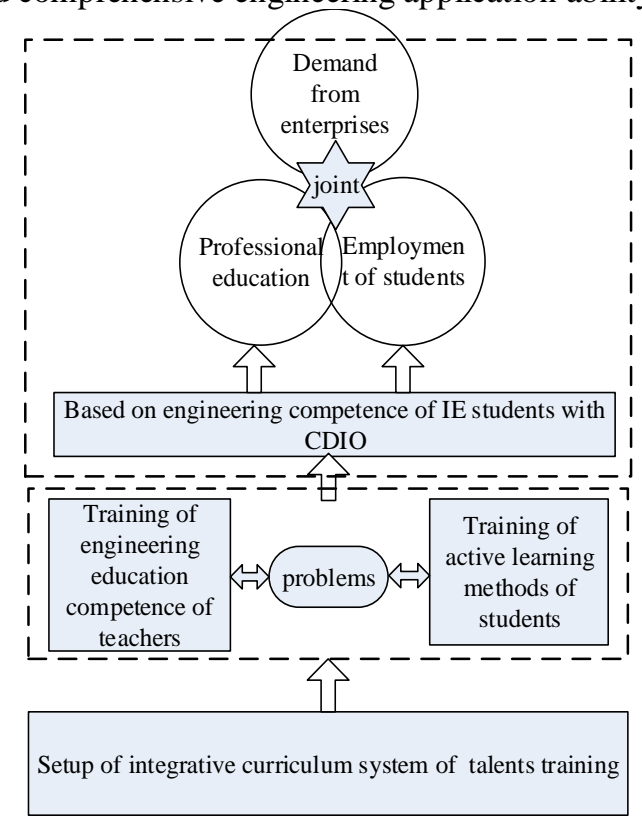

Figure 1. Basic idea of reformation of talents training mode

\section{B. Combination of Production and Teaching}

First, promote institution-enterprise cooperation, and understand that high quality engineering personnel should be produced jointly by higher education institutions and enterprises. Providing internship sites for students by enterprises will necessarily benefit the training of industrial personnel and also is a way for enterprises to fulfill their social responsibility. Enterprises should be more active to undertake engineering personnel training. Higher education institutions possess much scientific and technological human resources, so technological cooperation between with higher education institutions and enterprises can strengthen $R \& D$ and innovation capacities of enterprises, enabling them to achieve better competitiveness.

Second, use case study to improve the quality of practical teaching. In the process of teaching, teachers guide students through case study, with active participation of the students, to make students more active in learning before, during and after classes and trained for practical skills; students are required to complete tasks in groups, so that they gain communication and cooperation abilities and develop good sense of responsibility; also, students are 
required to find ways to solve problems by making good use of the knowledge they learnt and careful study, so that they get diverse thinking, the ability of knowledge learning and application as well as solving practical problems.

Finally, improve the practical engineering abilities of teachers. To employ "bi-teachers" to provide students with relevant cases and personal experience. Most of the teachers specialized in engineering education are academic type, while bi-teachers have rich experience of work in enterprises and engineering practice, so they can easily get students on track during engineering training.

\section{Determine the Targets According to Social Demands}

The higher engineering education in China should be adapted to the requirements of social development. The key features of senior engineering technicians needed in the future should be identified, and the higher engineering institutions in China should set their education targets according to their own positioning, and they should avoid blindly imitating others or bypassing the reality. In the future, there will be great demand for diversified higher engineering personnel, which include not only scientists but also technology-oriented, application-oriented and comprehensive engineering technical talents. The higher engineering education should commit itself to outputting high quality engineers suitable for the future development of China.

\section{Improving College-Enterprise Co-Operation}

Theoretical teaching contains a public basic course, professional basic course, professional required course and an elective course. Practical teaching covers experiments, internship, design, a graduation project and social practice. The aim of the reform of practical teaching is to strengthen students' integrated skills, innovation and overall quality. First, reform the experiments component of the teaching. By sharing resources and equipment, the number of participants engaged in specialized basic courses can be increased. Second is to build a high standard of staff able to deliver the engineering training. Skilled staff are needed, who have the capacity to develop high-level mechanical designs and understand manufacturing. Third is to enhance co-operation with companies to establish training bases and specialized laboratories that combine production, study and research. Fourth, the results of research should be used to promote practical teaching. The aim is to help students expand their horizons, enhance their teamwork, train their scientific thinking and boost their practical ability.

\section{REFORM OF TEACHING}

\section{A. Update Teaching Mode}

In the experimental teaching activities, the experimental project can be optimized and reorganized according to the basic type, design comprehensive and innovative experiments; to carry out experimental teaching in the order of easy to difficult and from simple to complex. The interaction between theory course and experiment course teaching, teaching activities and scientific research is added. To achieve the theory course can guide experiment course teaching, experiment course teaching can promote the understanding of theory course; Undergraduate students can participate in scientific research projects, new knowledge of scientific research, new theory into teaching activities, scientific instruments and equipment and teaching equipment are intercommunicating, scientific research and teaching on mutual promotion .

\section{B. Reform Teaching Method}

According to the characteristics of mechanical engineering experiments, the students' cognitive rules are considered comprehensively, and the teaching methods and models of students' self-training are established according to the characteristics of different subjects. The teacher uses the heuristic teaching method to teach the students the basic theory of the experiment, the experiment technique principle, etc., to mobilize the students' learning initiative, to understand the use of the experimental apparatus and equipment, to achieve the indigenous design of the experimental scheme, under the guidance of the teacher to complete all the experimental process. In the teaching should pay attention to broaden the students' knowledge, to carry out the experimental teaching of multidisciplinary, to encourage students to cross-discipline elective experimental course.

\section{Promoting Laboratory Network}

Through efficient and fast network, students can view the teaching syllabus, electronic teaching plan, and can download multimedia courseware, video and other teaching resources; students can better preview or review the content of the experimental course through the network, accurate grasp of the knowledge. Through the experimental teaching of the website, the students can carry out the network answer, but also can query the distribution and using condition of the laboratory. Promoting the construction of network and information in the laboratory can make the teachers and students more reasonable to arrange the experiment teaching content, and to improve the level of experiment teaching and working efficiency.

\section{V.Practical Measures}

\section{A. Graduation Design in the Enterprise}

The graduation design is a very important part of the practical teaching of mechanical engineering undergraduates. Its aim is to foster a student's ability to use the basic theory to solve practical problems. Senior students should undertake the graduation design by participating in a project in an enterprise. The proportion of participants who do this should gradually increase to ensure the authenticity and practicality of the graduation design topics.

To encourage students to combine professional knowledge and practice, colleges should encourage students to do their graduation design in the employment unit on-site, and should develop the management approach of students to make graduate designs in employment units. This ensures that a student's graduation design works smoothly in the field and is safe and of good quality. Colleges should sign an agreement with the organizations that provide sites for graduation design to provide accident insurance for students. The school should arrange an onsite mentor to guide students, and invite companies to 
participate in reviewing and questioning the graduation material.

\section{B. Take Advantage of Co-operative Laboratories}

Co-operative laboratories can be established by schools and enterprises, although with different respective roles. It is very efficient for universities and enterprises to share laboratories. Such a laboratory provides an effective solution to the shortage of university funding. Mechanical test equipment is expensive, and the corporate investment in equipment would greatly ease the financial pressure. Advanced technology enterprises are the most likely source of a co-operative laboratory. Because of the inseparability of enterprises and social needs, these laboratories bring with them new technologies and new knowledge, thus, ensuring they are advanced technology laboratories. In school-enterprise co-operative laboratories, company engineers would have more advanced technology knowledge and practical experience, while the university teachers have profound theoretical knowledge. So, they enhance each other. Finally, this method enhances practical teaching.

\section{Strengthen Teachers' Teams}

Universities should encourage young teachers to train in an enterprise for more than one year to closely integrate with engineering practice and, hence, enhance their practical teaching. The university may invite experts and senior technicians as part-time teachers of mechanical engineering majors. They would form part of an open teaching team composed of lab instructors, technical personnel of the training center and part-time teachers with extensive practical experience. Introducing enterprise personnel into institutions not only helps students about business and the application of professional knowledge, but also sets an example to teachers on linking theory with practice.

\section{Strengthen Training Bases}

The training base is used for teaching and is not a laboratory. It is designed to simulate operational practice, which cannot be completed in a classroom or laboratory. It is used to conduct systematic and normative training of basic skills, which is purposely designed to simulate real positions. The outside training base is used for on-site training, with direct participation in production and practical work. Through visits and internships, it can broaden students' horizons and improve ability and research via practice. It is a necessity if students are to go directly into working. With the application of advanced technology and equipment, the outside training base is becoming an essential part of helping graduates adapt quickly to their jobs.

\section{E. Enhance Students' Social Practice}

Students' social practices are an extension of the classroom teaching. To solve specific problems, students use their knowledge by selecting relevant information from memory. They should learn to verify theory knowledge and form an overall judgment on how to solve a problem. This practice not only helps students consolidate knowledge, but also encourages them to learn to change abstract theory into practical knowledge. Finally, it can enrich and expand the existing knowledge structures, promote the transformation of theoretical knowledge into practical capability for use in future work and lays a good foundation for solving new problems.

\section{CONCLUSIONS}

China is striding forward from large country in engineering education to a powerful country, the rapid development of social economy not only changes the people's production and life style, but also puts forward higher requirements for engineering education, the engineering practice ability and innovative spirit of the mechanical engineering students are becoming more and more obvious. To innovation consciousness, innovation ability training as the goal, the talent quality assurance as the fundamental, based on the discipline construction and the cultivation of professional talents, the overall level of mechanical engineering experiment teaching can be effectively improved through the reform of the experimental teaching system and the open experimental teaching mode. To cultivate students' scientific experiment ability, comprehensive design ability and product innovation ability has played a good effect.

While focusing on the development of applicationoriented talents along with the emphasis on strong foundations of theoretical knowledge, attention was paid to cultivating the ability of students to apply their engineering knowledge in a practical setting. Through the new education mode, an innovative method for talent cultivation with engineering applications in mind was achieved.

Application of the new cultivation mode to teaching has obviously improved its quality when compared with the traditional pattern of teaching. The practical ability of students has been significantly improved and employment rates and quality have improved. The students received good grades in various subject contests, and there have been more than 160 award-winners in national and provincial innovative games. The students obtained the national first prize in the competition for Mechanical Innovation Design in 2015. In addition, the graduates receive acclaim for their outstanding ability.

This innovative method has been demonstrated over recent years and has achieved satisfactory results. The use of these methods would allow successfully overcoming the bottleneck in the practice of application-oriented talent cultivation.

\section{ACKNOWLEDGMENT}

This research is supported by the teaching reform and research project of Suzhou University of Science and Technology in 2015 (2015JGM-20).

\section{REFERENCES}

[1] J. Jiang, "Exploration and Practice on Establishing Demonstration Centre of Mechanical Engineering Experimental Teaching", International Conference on Edcuation and Educational Research, pp.100-110, August 2013.

[2] Y.K. Sun, "On the cultivation of high-level applied talents in china's economic transformation period", Research in Higher Educ. of Eng., vol. 131, pp. 104-106, 2012.

[3] Z.H. Li, "Construction and practice on the training model of applied talents of mechanical engineering", J. of Changchun University of Science and Technol, vol. 24, pp. 122-124, 2011. 
[4] Q. Dong, "21 century industrial engineering construction and talent education", Consume Guide, Nov.2014.

[5] Z.J. Zhang, "Analysis on outstanding engineering cultivation in high engineering education", Heilongiiang Researches on Higher Education, vol. 12, pp. 140-141, 2010.

[6] J. LIN, "On the Professional Training Program of A Plan for Educating and Training Outstanding Engineers", Tsinghua Journal of Education, vol. 2, pp. 49-50, 2001.

[7] W. Liu, "Research on application-oriented talent cultivation mode in practice teaching", Experimental Technol. and Manage, vol. 26, pp. 123-127, 2009.
[8] F. Crawley, "To recognize the engineering education-international training mode and method", Higher Education Press, 2009.

[9] B. Zhou, "The new trend of development of the global manufacturing industry", http://www.drri.gov.cn/327491439/66829_17654.html, Oct.2009.

[10] H.P. Li, Y. Wang, "Nearly Major in machine of industry engineering professional training mode study practice", China Electric Power Education, vol. 131, pp.10-15, Jan.2011. 